УДК 519.9 : 316.612

В. І. БЕЗЛЮДНА, Л. П. ОСЬМАК

\title{
ДИСПОЗИЦЙНА ДЕТЕРМІНАЦІЯ НЕПРОДУКТИВНОЇ ВЗАЄМОДІЇ МІЖ ДІТЬМИ
}

Стаття висвітлює результати теоретичного і емпіричного аналізу проблеми сутності соиіальної взаємодії, їі стильових характеристик, особливостей неконструктивної взаємодї між дітьми у період старшого дошкільного віку. Здійснено аналіз особистісних спонук, які знижують ефективність спілкування та співпращі між дітьми. Обгрунтовується, щяо прагнення до домінування, визнання, самопрезентації, мотив дружби можуть видозмінювати стосунки між дітьми у процесі взаємодї та приводити до зниження ї̈ ефективності.

Ключові слова: сочіальна взаємодія, спілкування, співпраџя, непродуктивна взаємодія, дошкільний період.

Статья освещает результаты теоретического и эмпирического анализа проблемь сущности сочиального взаимодействия, его стилевых характеристик, особенностей неконструктивного взаимодействия между детьми в период старшего дошкольного возраста. Осуществлен анализ личностных мотивов, снижающих эффективность общения и сотрудничества между детьми. Обосновывается идея о том, что стремление к доминированию, признанию, самопрезентации, мотив дружбы могут видоизменять отношения между детьми в проиессе взаимодействия и снижать его эффективность.

Ключевые слова: сочиальное взаимодействие, общение, сотрудничество, непродуктивное взаимодействие, дошкольный возраст.

Постановка проблеми. Дошкільне дитинства - період інтенсивного формування міжособистісних стосунків між дітьми, засвоєння ними програм налагодження продуктивної взаємодії з оточуючими. Все ж, життєві спостереження та педагогічна практика засвідчують, що узгодженість у спілкуванні з ровесниками досягається дітьми далеко не завжди. Дітям дошкільного віку ще досить складно вирішити усі питання, які виникають у цій ситуації. На шляху до продуктивної взаємодії 3 ровесниками дитина зустрічається із зовнішніми та внутрішніми перешкодами. До зовнішніх можна віднести дію різноманітних ситуаційних чинників: нестача 
матеріалів, особливості їх використання. Внутрішні перешкоди пов'язані із психологічною готовністю дітей до взаємодії. У іiі структурі можна виокремити когнітивну складову (наявність системи знань про особливості діяльності та організацію співробітництва), систему практичних умінь для співпраці і нарешті мотиваційні основи активності, що складають диспозиційну основу взаємодії. Розлагодженість у любій із систем може знижувати ефективність спілкування, або ж взагалі приводити до непродуктивної взаємодії.

Аналіз останніх досліджень і публікацій дозволяє констатувати відсутність належної уваги до вищеозначеної проблеми. Дослідження вітчизняних і зарубіжних психологів переважно зосереджені на вивчення особливостей міжособистісних стосунків між дітьми, причин виникнення конфліктів у дитячих спільнотах. Тому можна виокремити незначну кількість робіт, які зорієнтовані на аналіз самого процесу дитячої взаємодії (В. Н. Белкіна, 1999; Л.В.Проніна,2009; С. Л. Шеліна, 2003; Ф. А. Шмідт, 2014). Зокрема у роботі С. Л. Шеліної висвітлено особливості засвоєння дітьми дошкільного віку когнітивних дії аналізу ситуацій інтеракцій, що лежать в основі вибору стилю досягнення мети [6]. У роботі запропоновано методику створення умов для формування усвідомленого, релевантного вибору дітьми способу взаємодії у різних ситуаціях. Автор доходить висновку, що продуктивним шляхом засвоєння дітьми дій аналізу ситуації інтеракцій є метод їх поетапного формування. Саме він, у подальшому здатний, забезпечити використання сформованих когнітивних умінь як засобів особистісної орієнтації. У роботі А. Ф. Шмідт обговорюються питання вікової генези взаємодії між дітьми у процесі спільної діяльності та вплив на цей процес організованих психолого-педагогічних програм (А. Ф. Шмідт, 2014 [7]). Автор доходить висновку, що діти усіх вікових підгруп дошкільного віку здатні до ефективної співпраці при вирішенні завдань продуктивного типу. Вони можуть самостійно планувати й розподіляти обов'язки між учасниками діяльності за принципами рівноправності та справедливості. У той же час, у дитячих групах існує принципова відмінність від дорослих колективів у розподілі функцій, задач, етапів, ролей. Це виявляється у самовисуванні (а не призначенні чи врахуванні кращого досвіду) та його груповому прийнятті. На думку автора, використання у роботі з дітьми ігрових ситуацій, які безпосередньо не спрямовані на створення певного продукту, але передбачають самостійне узгодження дітьми завдань, етапів, процесів, матеріалів, необхідних для досягнення поставленої мети, $є$ ефективними для формування навичок спільної продуктивной діяльності. Діти дошкільного віку набувають здатність до екстраполяції знань і умінь, отриманих в ігровій ситуації, на виконання продуктивних завдань. Найбільш ефективним цей прийом виявився для дітей молодшого дошкільного віку [7, с. 257]. Цікавими є дослідження американських психологів (К. Pierc, L. Schreibman 2007 [8]; К. Pierce, L. Schreibman 1997; Sherer 2001) з розвитку базових соціальних навичок у аутичних дітей через організацію взаємодії з однолітками-котерапевтами. Пройшовши спеціальну підготовку, однолітки отримують здатність долучатися до психотерапевтичного процесу за програмою «Навчання ключовим навичкам» (Pivotal response training) як його повноправні учасник.

Для нашого дослідження особливу значущість мають робота В. Н. Белкіної щодо особливості взаємодії між дітьми у період дошкільного дитинства [1, с. 116-121] та ії рівневих характеристик [3]. На думку цього автора, у структурі взаємодії дітей у процесі спілкування та спільної діяльності можна виокремлювати три компоненти: когнітивний, емоційний і операційний. Кожний із них $\epsilon$ багатоаспектним, тому включає різні за своєю сутністю і спрямуванням елементи. Зокрема, у когнітивному компоненті автор виокремлює різні параметри усвідомлення дітьми комунікативної взаємодії: від іiі цільових та процесуальних аспектів до результативних. Цей компонент реалізується у таких параметрах, як усвідомлення та прийняття дітьми цілей взаємодії як спільної, усвідомлення власних мотивів взаємодії та мотивів партнерів; вибір оптимальних способів досягнення цілі, усвідомлення рівнів власних умінь і навичок, а також умінь і навичок партнера, його особистісних властивостей, аналіз спільного і особистісного результату.

Аналізуючи структуру емоційного компоненту В. Н. Белкіна наголошує, що сюди віднесені не лише емоційні переживання, що виникають у процесі спільної діяльності, а й мотиваційні спонуки: наявність прагнення дитини до налагодження взаємодії, бажання чи не бажання приймати мотиви партнера. Доречність об'єднання емоційних і мотиваційних елементів пояснюється віковою специфікою розвитку мотиваційної сфери у період дошкільного дитинства. На цьому етапі онтогенетичного розвитку мотиви взаємодії з партнерами не стільки усвідомлюються дітьми, скільки емоційно переживаються ними [3, с. 113]. Все ж, за нашим розумінням, мотиваційний компонент заслуговує на самостійне виокремлення та аналіз навіть відносно періоду старшого дошкільного дитинства. Здатність дітей обговорювати і інтерпретувати свої бажання вказує на виокремлення у їхній свідомості спонукального аспекту діяльності та, відповідно, на його вплив на організацію діяльності та спілкування. До того ж ми не зустріли робіт, які б грунтовно висвітлювали мотиваційні 
основи взаємодії між дітьми, особливо при іï непродуктивних формах. За нашим розумінням, ці прогалини у науковому пізнанні перешкоджають розробці програм стимулювання та корекції соціальної взаємодії у дитячих спільнотах, розвитку у дітей належного рівня комунікативної компетентності.

Формулювання цілей статті. У своєму дослідженні ми зробили спробу проаналізувати мотиваційне підгрунтя непродуктивних контактів між дітьми, виокремити і описати диспозиційну детермінацію їх неузгодженої поведінки з партнерами.

Виклад основного матеріалу дослідження. У психологічній науці соціальна взаємодія інтерпретується як процес прямого чи опосередкованого впливу людей один на одного, що породжує ïx взаємну зумовленість та зв'язок [5, с. 193]. Унікальна значущість цього явища дозволила виокремити його як одну із центральних ліній аналізу комунікативної діяльності людини інтерактивну. На сьогодні виконано ряд досліджень у вітчизняній і зарубіжній психології, присвячених вивченню різних аспектів міжособистісної взаємодії (Г. М. Андрєєва, В. В. Абраменкова, О.О.Бодальов, Л. І. Божович， В.В.Давидов， М. І. Лісіна, Я. Л. Коломінський, В. М. Мясіщев, Є.В. Субботський, Т. О. Репіна, Д. Б. Ельконін, А. Бандура, Ж. Піаже, Л. Кольберг, М. Блатт, Т. Шибутані, Е. Еріксон та ін.). Психологічна наука відповіла на багато питань щодо форм організації процесу соціальної взаємодії. Все ж, онтогенетичні аспекти непродуктивної взаємодії і на цей час залишаються недостатньо висвітленими.

Перш за все коротко зупинимося на сутності поняття «непродуктивна взаємодія». Як зазначається у соціальній психології, взаємодія завжди представлена двома компонентами: змістом i стилем [5, с. 195]). Саме при аналізі стильових характеристик інтеракцій і використовується дефініція «непродуктивність». Під непродуктивним стилем взаємодії розуміють нерезультативний спосіб контакту партнерів, який блокує як реалізацію особистісного потенціалу, так і досягнення оптимальних результатів спільної діяльності.

При диференціації стилів взаємодії за критерієм «продуктивність-непродуктивність» використовуються наступні критерії:

- особливості активності 3 точки зору позицій партнерів («поряд 3 партнером продуктивний стиль; «над партнером»- непродуктивний стиль);

- особливості цілей (у продуктивному стилі партнери разом виокремлюють як близькі, так і далекі цілі взаємодії; у непродуктивному - домінуючий партнер пропонує лише близькі цілі, не обговорюючи їх з партнером);

- особливості відповідальності (у продуктивному стилі відповідальність за результати діяльності покладається на усіх учасників; у непродуктивному - відповідавльність монополізує домінуючий партнер);

- особливості стосунків між партнерами (у продуктивному стилі - доброзичливість і довіра; у непродуктивному - агресія, образа, роздратування;

- особливості механізмів ідентифікації-відокремлення між партнерами [5, с. 195].

Непродуктивність взаємодії між дітьми може залежати від значної кількості змінних. Визнаючи вплив сукупності чинників, у своєму дослідженні ми акцентували увагу на диспозиційній складовій. Ми ставили перед собою завдання виокремити мотиви, які здатні послабити співпрацю між дітьми та спричинити ii непродуктивність. Робота виконана на основі методу включеного спостереження за процесами взаємодії дітей в умовах дошкільного закладу. У дослідженні брали участь діти старшого дошкільного віку. Зазначимо, що проблемні ситуації конфліктного характеру, які висвітлювали ознаки застосування дітьми непродуктивних стилів впливу (вербального чи невербального характеру) по відношенню до партнерів без входження партнерів у процес взаємодії нами не враховувалися. Для аналізу використовувалися лише сюжети реальної розгорненої взаємодії.

За результатами виконаного спостереження до розряду мотивів, що здатні надати процесу взаємодії ознак непродуктивності, віднесені наступні спонуки: мотив змагання, презентаційна мотивачія, потреба у визнанні, прагнення до домінування над партнером, бажання керувати процесом діяльності чи визначенням мети співпраці, мотив дружніх стосунків, деривачія матеріальних потреб.

Перш за все зупинимося на аналізі функціонування мотиву змагання. У повсякденному житті елемент конкурентності у спільній діяльності дітей присутній досить часто. Прийняття ідеї змагання посилює егоїстичні тенденції, запускаючи механізм прагнення до отримання особистісних переваг. Цільові аспекти спільної діяльності у цьому випадку зміщуються із ії кінцевої результативної мети на особистісне домінування. Проілюструємо це на прикладі. 
Двоє дітей, Таня і Орест, отримали завдання підготувати столи до обіду. Діти вирішили виконувати роботу на швидкість $і$ кинулись розставляти тарілки, відштовхуючи один одного. Таня вихопила посуд із рук Ореста. Дві тарілки впали і розбилися. Хлопчик поранив палещь.

Простеження процесуального аспекту взаємодії цих дітей засвідчує, що первинне прийняття спільного завдання розгорталося на фоні різних особистісних устремлінь. Дівчинка не лише зраділа дорученню, а й спробувала доказати хлопчику, що вона краще впорається з роботою. Ї̈̈ партнер особливого бажання виконувати доручення не мав. Йому сподобалася лише ідея змагання. I хоча кожний із них вніс свій вклад у неконструктивність взаємодії, провину визнала лише дівчинка. У іiі емоційних реакціях простежувалося і каяття, і страх, і співчуття. Натомість хлопчик демонстрував лише гнів та образу, звинувачуючи, у всьому що сталося, свого партнера. Як бачимо, змагальна мотивація вплинула як на перебіг процесу виконання спільного завдання, так і на прийняття та оцінювання наслідків.

Мотив змагання може спричиняти як вибір нерелевантних шляхів виконання завдань, так i призводити до порушення моральних норм взаємодії. Особливо, коли до особистісного прагнення отримати перемогу додається мотив презентаційного провалу. Проілюструємо це на прикладі.

Під час проведення спортивних змагань «Козаџькі забави», у завданні «Перегони» брали учать двоє хлопчиків Андрій і Рустем. Коли половина шляху була вже подолана, Рустем зрозумів, шо не зможе перегнати напарника. Хлопчик підставив підніжку для свого суперника. Андрій впав, пошкодивши ногу. Гру зупинили.

Присутність презентаційної мотивації чітко прозвучала у звертанні Рустема до постраждалого. «Вибач, я не хотів, щоб тобі було боляче. Це все через них». Виявилося, що перед початком змагання діти з команди Рустема глузували з його невисокого зросту та висловлювали недовіру до його можливостей. Почувши ці глузливі вигуки, ображений хлопчик вирішив, що має виграти перегони любим способом. Виправдовуючись перед вихователем, хлопчик, зі сльозами на очах, відзначав, що не хотів нікому завдавати шкоди, йому лише хотілося щоб діти його поважали і не насміхалися.

Потреба у визнанні, як важливий показник особистісного становлення дитини, також може спричиняти загострення стосунків між партнерами та послабити мотивацію до співпраці. Це яскраво простежується у наступному сюжеті.

Діти збирались на денну прогулянку. Після того, як вихователька наголосила, що всі чекають лише Артема, однолітки і вихователь почали швидко допомагати хлопчику одягатися. Марійка, стоячи поряд, ревниво спостерігала за ситуачією та ображено поглядала на виховательку, яка не похвалила ї̈ за старанність і спритність. Врешті-решт, щоб привернути увагу до себе, дівчинка почала голосно сваритися з Артемом за начебто забруднені ним речі. При ивому вона наголошувала на своїх уміннях та постійній допомозі хлопчику, що і видавало ї̈ бажання отримати похвалу.

Цей приклад засвідчує, що не отримавши визнання за свою попередню співпрацю 3 однолітком дівчинка втратила бажання приймати участь у наданні допомоги, хоча, як зазначає вихователь, завжди робила це залюбки.

Взаємодія завжди передбачає як мінімум двох учасників. Успішність їх співпраці у діаді значною мірою зумовлена готовністю приймати статусні позиції один одного. Прагнення до домінування у цьому випадку не лише знижує ефективність спілкування, а й надає взаємодії неконструктивного характеру Бажання керувати партнером перешкоджає здійсненню програм взаємоузгодження позицій і прийняття статусу іншого учасника взаємодії.

Під час прогулянки вихователька доручила Даниїлу та Марку виконати роль ведучих при розподілі ролей. Діти почали домовлятися між собою, але досить швидко між ними виникла суперечка, хто ж головний. Поступово спір досяг апогею і хлопщі побилися. Гра не відбулась.

Аналіз поведінки дітей засвідчує, що основне протистояння у цьому випадку виникло із-за бажання кожного керувати одноосібно, не визнаючи прав іншого учасника. При цьому діти використовують різні аргументаційні доведення, щоб відстояти свою позицію. «Він не може бути головним! - відзначає Даніїл. - Мене вибрали ведучим першим, бо я швидкий і розумний». «Ні, ти не будеш мною командувати! Це ти мусиш слухатися мене! - стискаючи кулаки, викрикує у відповідь Марко, - Я все-одно буду головний!».

Як бачимо, звичка домінувати у стосунках спричинила протест та незгоду дітей поступитися статусом та прийняти рольові позиції іншого. Їх взаємодія, розпочинаючись як конструктивна, поступово зруйнувалася, не принісши бажаного результату.

Бажання домінувати може містити різну змістову модальність У одних випадках воно спрямоване відносно партнера, оскільки він сприймається як менш гідний, щоб зайняти домінуючі позиції (це ілюструє попередній сюжет). У іншому - дитячі устремління зорієнтовані на прагнення 
домінувати в плані організації діяльності, визначенні мети спільної діяльності та їі процесу. Їх успішність чи провальність значною мірою обумовлюються рівнем просоціальності поведінки. Як засвідчують наукові дослідження у період дошкільного дитинства, на зміну афективним реакціям про соціального типу приходять дії, засновані на процесах соціального пізнання. Когнітивна сфера починає виконувати центральну функцію у виборі стратегій поведінки (Н. В. Корчакова [4, с. 196]).

Покажемо це на конкретному прикладі поведінки двох подруг, між якими розгорівся конфлікт, хоча зазвичай дівчатка співпрацюють досить дружно. Протистояння виникло у зв'язку 3 відмовою однісї із подруг прийняти ідею іншої щодо сюжету гри (див. табл.1).

\section{Зміст непродуктивних транзакцій у дитячій взаємодії}

Табличя 1.

\begin{tabular}{|l|l|}
\hline \multicolumn{1}{|c|}{ Змістові показники дитячих транзакцій та зміна емоційних станів партнерів } \\
\hline \multicolumn{1}{|c|}{ Влада } & \multicolumn{1}{|c|}{ Поліна } \\
\hline Ходімо гратися в «Доньки-матері» & $\begin{array}{l}\text { Нi, краще давай пограємо у «Магазин». Я - } \\
\text { продавець. }\end{array}$ \\
\hline Будемо гратися, як я сказала & Не хочу! \\
\hline Чого стоїш? Ну, пішли вже! & Сказала, не буду! \\
\hline $\begin{array}{l}\text { А ще подруга! Я з тобою теж не гратимуся (продовжує } \\
\text { наполягати, наступаючи на подругу)! }\end{array}$ & $\begin{array}{l}\text { Моя гра цікавіша Я краще придумала (говорить } \\
\text { гнівно і голосно)! }\end{array}$ \\
\hline $\begin{array}{l}\text { Тільки спробуй піти !!! (проговорює із гнівом та } \\
\text { погрозою у голосі) }\end{array}$ & $\begin{array}{l}\text { Не хочу я з тобою гратися. Ти погана (у очах } \\
\text { дівчинки бринять сльози, у голосі тремтіння). }\end{array}$ \\
\hline
\end{tabular}

Такий тип конфліктів переважно розгортається при виборі дітьми неправильного стилю спілкування. Варто відзначити, що на думку В. Н. Белічевої таке інтегративне особистісне утворення як стиль взаємодії уже чітко простежуються у поведінці дітей дошкільного віку. Його особливості можна характеризувати 3 декількох позицій. За ознакою мотивації дитина може вести себе альтруїстично, колективістично, вибірково та егоїстично. За переважаючим емоційним станом іiі взаємодія з партнерами може бути доброзичливо-активною, доброзичливо-пасивною, агресивною. За спрямуванням цілей взаємодія може розгортатися як конструктивно-творча чи як руйнівна. За переважаючим способом зв'язхків з однолітками взаємодія морже набувати форми керування, співпраці, змагання, подавлення, підкорення [2, с. 293].

Використання одним із партнерів наказових форм впливу, здійснення ним певних утисків знижує бажання іншого учасника працювати в діаді. Якщо спілкування започатковується у такій модальності, взаємодія переважно припиняється навіть не розпочавшись. За цих умов страждають як стосунки між дітьми, так і емоційний стан кожного із партнерів. Важливим аспектом взаємодії $€$ результат спільної активності. В ігровій діяльності він зарані чітко не заданий і $\epsilon$ продуктом спільного інтелектуального пошуку, який містить ідеї обох учасників, або ж згоду одного із партнерів з ідеями іншого. У реальних життєвих ситуаціях ця згода досягається не завжди. Як наслідок виникає проблемна ситуація, коли партнери пропонують певні ідеї та роблять спробу відстояти свою позицію. Одним із прийомів протидії $\epsilon$ спроба виокремити власний підхід та перешкодити партнеру у здійсненні його програми.

Сашко Г. й Ілля П. разом будують з конструктора замок. Хлопчики не змогли домовитись про його конструкиію, тому почали сперечатися. Сашко будував по-своєму, а Ілля розбирав замок, який, за його словами, «побудований неправильно».

Дружні теплі стосунки між хлопчиками поступово наповнювалися негативними тенденціями. Міжособистісний простір дестабілізувався. Між дітьми почала простежуватися образа, неприйняття, впертість, злість. Врешті-решт емоційний фон спілкування став настільки деструктивним, що спровокував як розрив зв'язків між дітьми, так і незавершеність справи. Все ж необхідно визнати, що неприйняття учасниками взаємодії способів виконання завдання кимось із партнерів не обов'язково негативно позначається на результаті діяльності. Навпаки, у деяких випадках, неузгодженість позицій може сприяти підвищенню консолідації інших учасників ігрової спільноти. З'являються спроби презентувати успіхи підгрупи, яка позначається через категорію «Ми» та протиставити їх активності небажаного партнера. При оцінюванні результату діти схильні висловлювати критичні зауваження на адресу партнера, який не прийняв їх вказівки чи покинув ігровий простір.

Важливу роль у організації взаємодії і ії результативності мають особистісні стосунки. Дружба між дітьми сприяє гармонізації співпраці. До того ж із середнього дошкільного віку 
спостерігається усвідомлення дітьми значущості дружніх зв'язків з партнерами та використання цих особливостей стосунків не лише у ситуації прийняття певного особистісного рішення, а й при тлумаченні власних позицій. Все ж така мотивація може мати і негативний вплив на активність дітей та пї результати.

Під час сніданку Аня і Марійка розпочали гру маленькими маріонетками. На зауваження виховательки Аня відповіла, щьо їсти молочну кашу вона не буде, тому краще пограється. Те ж саме відповіла і ї̈ подруга, хоча зазвичай їла кашу із задоволенням.

Вербальні транзакції подруг подані у таблиці (див. табл. 2)

Зміст вербальних транзакцій на основі мотиву дружби

Таблиия 2.

\begin{tabular}{|l|l|}
\hline \multicolumn{2}{|c|}{ Вербальні транзакції } \\
\hline \multicolumn{1}{|c|}{ Висловлювання Ані } & \multicolumn{1}{|c|}{ Висловлювання Марійки } \\
\hline Я не люблю цю кашу! & Аня не їсть, то і я не буду! \\
Не хочу їсти. & Вона моя подружка, ми будемо разом не їсти. \\
Мені мама таку кашу не дає! & Я не голодна, вдома поснідала. \\
\hline
\end{tabular}

Аналіз неконструктивної взаємодії між дітьми з точки зору їі мотиваційних основ дозволяє більш чітко визначати напрям психолого-педагогічної корекції дитячого спілкування та співпраці, що в цілому сприятиме оптимізації виховних стратегій та гармонізації стосунків між дітьми.

Висновки та перспективи подальших розвідок.

Взаємодія між дітьми - основа співжиття дітей в організованих спільнотах. Рівень ії конструктивності позначається як на загальній атмосфері групи, так і на самопочутті кожної дитини. Корекція неконструктивної взаємодії буде успішною за умови урахування іiї мотиваційних основ.

\section{Список використаних джерел}

1. Белкина В. Н. Психология раннего и дошкольного детства / В. Н. Белкина. - М. : Юрайт, 2018. $-170 \mathrm{c}$.

2. Белкина В. Н. Психологические аспекты взаимодействия детей дошкольного возраста со сверстниками в контексте современных требований к дошкольному образованию / В. Н. Белкина // Ярославский педагогический вестник. - 2012. - № 1, т. II. - С. 291-294.

3. Белкина В. Н. Уровни взаимодействия детей дошкольного возраста со сверстниками / В. Н. Белкина // Ярославский педагогический вестник. - 1999. - № 3 (21). - С. 112-116.

4. Корчакова Н. В. Просоціальність особистості: становлення та розвиток : монографія / Н. В. Корчакова. - Рівне : Волин. обереги, 2017. - 440 с.

5. Крысько В. Г. Психология. Курс лекций : учеб. пособ. / В. Г. Крысько. - М. : Вуз. учеб., НИЦ ИНФРА-М, 2017. - $251 \mathrm{c}$.

6. Шелина С. Л. Формирование действий анализа ситуации интеракции у детей и взрослых : дисс. ... канд. психол. наук : 19.00.07 - пед. психология / С. Л. Шелина. - М., 2003. - 163 с.

7. Шмидт А. Ф. Психолого-педагогические условия продуктивной совместной деятельности дошкольников / А. Ф. Шмидт // Ярославский педагогический вестник. - 2014. - № 4, т. II. - С. 254 258.

8. Kids Helping. Kids Teaching Typical Children to Enhance the Play and Social Skills of their Friends with Autism and Other PDDs : A Manual by Karen Pierce [Electronic document]. - Ph.D. \& Laura Schreibman, Ph.D., 2007. - Access mode : https://autism-center.ucsd.edu/autisminformation/Documents/Peer\%20training\%20manual2007.pdf.

\section{References}

1. Belkina V. N. Psikhologiya rannego i doshkolnogo detstva / V. N. Belkina. - M. : Yurayt. 2018. $170 \mathrm{~s}$.

2. Belkina V. N. Psikhologicheskiye aspekty vzaimodeystviya detey doshkolnogo vozrasta so sverstnikami $\mathrm{v}$ kontekste sovremennykh trebovaniy $\mathrm{k}$ doshkolnomu obrazovaniyu / V. N. Belkina // Yaroslavskiy pedagogicheskiy vestnik. - 2012. - № 1, т. II. - S. 291-294.

3. Belkina V. N. Urovni vzaimodeystviya detey doshkolnogo vozrasta so sverstnikami / V. N. Belkina // Yaroslavskiy pedagogicheskiy vestnik. - 1999. - № 3 (21). - S. 112-116.

4. Korchakova N. V. Prosocialnist osobystosti: stanovlennya ta rozvytok : monografiya / N. V. Korchakova. - Rivne : Voly`ns`ki oberegy`, 2017. - 440 s. 
5. Krysko V. G. Psikhologiya. Kurs lektsiy : ucheb. posob. / V. G. Krysko. - M. : Vuz. ucheb. NITs INFRA-M., 2017. - $251 \mathrm{~s}$.

6. Shelina S. L. Formirovaniye deystviy analiza situatsii interaktsii u detey i vzroslykh : dis. ... kand. psikhol. nauk : 19.00.07 - ped. psikhologiya / S. L. Shelina. - M., 2003. - 163 s.

7. Shmidt A. F. Psikhologo-pedagogicheskiye usloviya produktivnoy sovmestnoy deyatelnosti doshkolnikov / A. F. Shmidt // Yaroslavskiy pedagogicheskiy vestnik. - 2014. - № 4, т. II. - S. 254-258.

8. Kids Helping. Kids Teaching Typical Children to Enhance the Play and Social Skills of their Friends with Autism and Other PDDs : A Manual by Karen Pierce [Elektronnyy dokument]. - Ph.D. \& Laura Schreibman, Ph.D., 2007. - Rezhym dostupu: https://autism-center.ucsd.edu/autisminformation/Documents/Peer\%20training\%20manual2007.pdf

\section{I. Bezludna, L.P. Osmak DISPOSITIONAL DETERMINATION OF UNPRODUCTIVE INTERACTION BETWEEN CHILDREN}

Article highlights the issues of interaction between children during the preschool childhood period. Interaction nature as transactional system and its stylistic characteristics have been discussed. The indicators of productive and non-productive interaction, their criteria indicators have been determined. Features of children's learning cognitive actions of the interaction situation analysis underlying the choice of the goal achieving manner have been highlighted on the basis of research analysis. The issues of studying the age genesis of interaction between children in the process of joint activities and the impact of organized psychological and pedagogical programs on this process have been discussed. Article analyzes the structure of social interaction, highlights its main components: cognitive and emotional. It is noted that it is also appropriate to highlight the motivational structure of social interaction of children.

The empirical information has been obtained by using the method of participant observation. Term paper highlights the motives, actualization of which leads to emergence of productivity absence in communication and joint activities of children. The motives of this group include the following: competition reason, presentation motivation, recognition needs, and desire to dominate the partner, desire to manage the process of activity or the definition of the cooperation purpose, reason for friendly relations. It has been noted that the organization of developmental and correctional work with children should take into account the dispositive basis of unproductive interaction.

Key words: social interaction, communication, cooperation, unproductive interaction, preschool period. 